\title{
Effectiveness of the Privatization Process on the Government Coconut Plantation Companies in Sri Lanka
}

\author{
N D S R GUNASEKERA \\ Lecturer, Association of Accounting Technicians of Sri Lanka \\ No. 540 Thimbirigasyaya Road Colombo \\ sri.gunasekera@hotmail.com
}

\section{S C THUSHARA}

Lecturer, Department of Commerce and Financial Management, Faculty of Commerce and Management Studies, Univeristy of Kelaniya, Kelaniya, Sri Lanka scthushara@kln.ac.lk

\section{N RANASINGHE}

Lecturer, Department of Commerce and Financial Management, Faculty of Commerce and Management Studies, Univeristy of Kelaniya, Kelaniya, Sri Lanka dinithi@kln.ac.lk

\begin{abstract}
During the past three decades economic reforms in the world were designed to expand the role the market economy through privatization. Most of the researchers have strongly documented that after being privatized, firms became more profitable and operating efficiency and dividend payments have significantly improved. The economic turnaround in Sri Lanka came about in 1990's, most of the public sector commercial organizations including the plantations managed under public sector were privatized.

This research compares the financial performance, physical performance and employee perception of the two coconut plantation companies under the management of private sector and government during the period from 2000 to 2009. Data was collected using annual reports, progress reports of the Kurunegala Plantations Limited and Chilaw Plantations Limited and questionnaire of the two companies. Data was analyzed by using descriptive statistical methods such as mean, standard deviation, co-relation and co-efficient. It is documented that significant improvements in financial performances, physical performance and employees' satisfaction of both the companies under government management. When compared with the previous studies these results strongly reject that private management system is more efficient than government management.
\end{abstract}

Keywords: privatization, plantation management, economic reforms, liberalization 


\section{Introduction}

The plantation system established by the colonial rulers in Sri Lanka had transformed the economy from closed feudal agrarian subsistence status in to a dual economy comprising a plantation sector and a subsistence agrarian sector (Karunaratne, 1973). This economy was later branded as an export economy due to the fact that all important macro-economic variables were dependent upon the level of export income (Snodgrass, 1966). Under these circumstances, the plantation sector became the engine of the economy of Sri Lanka up to 1970s (De Silva, 1977).

In 1970, the government formed by Sri Lanka Freedom Party with two Marxist Parties introduced a large scale programme of land reform in 1972, and nationalized the plantations owned by private land owners. Most of the plantations nationalized under land reforms in 1972, were handed-over to the Sri Lanka State Plantation Corporation (SLSPC) and Janatha Estate Development Board (JEDB) established in 1972.

The government formed by United National Party (UNP) in 1977 revitalized economic policies implemented by the previous government with wide ranging reforms. The Government formed by the Public Alliance (PA) continued the same economic policies up to year 2004. Most of the public sector commercial organizations including the plantations sector were privatized under the privatization strategy implemented during the period 1977 2004.

Government sector plantations managed by the SLSPS and JEDB were leased out to twenty three (23) Regional Plantations Companies (RPC) established under the companies act No 17 of 1982 during the period 1992-1994. At the same time government entered in to management agreements with some private sector companies to manage a few regional plantation companies. Kurunegala Plantations Limited and Chilaw Plantations Limited are among a few of them.

The privatization process has been suspended since 2006 under the "Mahinda Chinthana" policy as the government has decided to repossess some of the privatized organizations including regional plantation companies due to failure in achieving expected targets under privatization. 
Kurunegala Plantations and Chilaw Plantation are coconut plantation companies, reprocessed in 1995 and 1998 respectively due to failure in achieving expected results under privatization. At the time of writing, Kurunegala Plantations has been converted to a profit making business organization under the public sector management and Chilaw Plantations also managed as a profit making public sector organization from 2008 to 2009 under the public sector management with considerable improvements (Annual reports of Kurunegala Plantations Ltd-, 2000 -2009 and Chilaw Plantations Ltd.-2008-2009).

Main objective of this research is to evaluate the performance of two coconut plantation companies under private management and government management. Ancillary objectives are to measure financial performance of two companies under two different management systems, measure non- financial performance of two companies under the two different management systems and compare the performance of each company under different management systems.

This research is significant to policy makers in order to determine whether entrepreneurship of the coconut plantations should be under private sector or public sector for national development, formulate specialized management style for coconut plantations and determine national agriculture policies for coconut plantations. Further the research is also significant to the researchers in order to analyze the success and weaknesses of the private sector management in the coconut plantation industry and analyze the success and weaknesses of the public sector management in the coconut plantation industry.

In the study performances under different managements are considered as dependent variables against the independent variables of changes of the managements of the companies under conceptual frame work. Performances are limited to financial, non-financial and employee satisfaction.

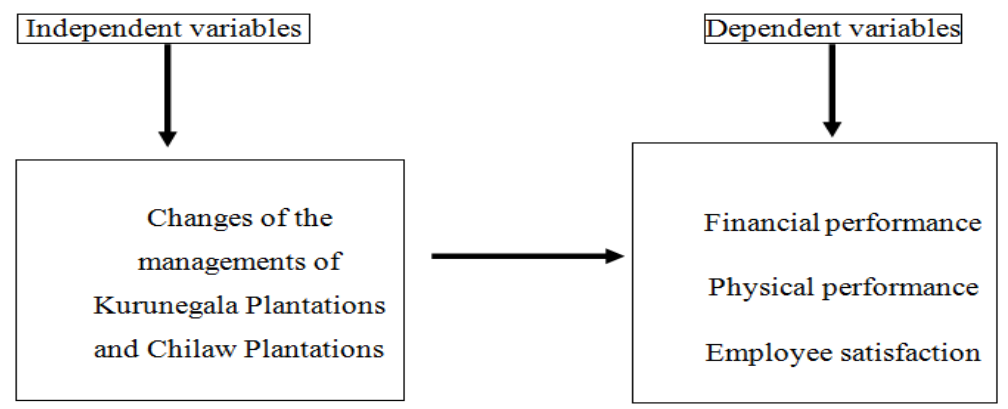

Figure 1.1: Conceptual frameworks 


\section{Literature Review}

\section{History of Nationalization}

After World War II socialist governments came in to the power in several countries and set about nationalizing heavy industry, especially coal. Many Europeans wanted strong state action to ensure economic developments since they blamed the timidity and conservatism of private capital for economic dislocations of the 1930's (Millward, 1997). Nationalization in Britain, concentrated economic planning in France, and a low- key economic management in Germany all grew out of this same pulse. Many of the smaller nations also utilized the central economic planning in some form (Millward, 1995).

Nationalization was voted by parliament for Bank of England, coal mining, hospitals, the iron and steel industry, communication, gas and electricity production and railways (Abromeit, 1986). Most of Europe's coal mines passed in to effective government control, with the British coal mines being nationalized under control of the National Coal Board. The plan to nationalize the coal mines had been accepted in principle by owners and miners alike before the election of 1945 (Arhworth, 1986). In 1974 the Labour government nationalized all the airlines and merged them in to British Airways. In 1975 the labour government under Harold Wilson nationalized the shipbuilding industry in response to the demand of the workers (Johnman, 1996). In Eastern Europe, communist governments nationalized all the mines and factories after 1945. One German state, controlled by the socialists passed a bill in North Rhine-Westphalia in 1948 to nationalize basic industries Lieberman, 1981).

\section{Nationalization in Sri Lanka}

During the period 1954-1956 the government took steps to enact several acts to commence the semi-government enterprises (Government Corporations (1953) \& Government Sponsored (1955)). Activities such as banking, plantations, large scale industries, transport, insurance, telecommunications, postal services, ports, electricity, imports and distribution of petroleum products, health and education were either monopolized by the public sector or under taken by the state enterprises.

The dominant role played by the state during the period 1950 to 1977 by setting up public enterprises, monopolies and nationalization of selected private enterprises showed a dramatic 
increase in performance from 1950 till mid 1970s (Central Bank annual report of Sri Lanka 1988:211).

\section{History of Privatization}

The history of privatization dates back to ancient Greece, when government contracted out almost everything to the private sector. In the Roman Empire, private individuals and companies performed majority of the services including collections of taxes. In more recent times, Winston Churchill's government privatized the British steel industry in the 1950's.West Germany government embarked on large- scale of privatization. In the 1970s General Pinochet implemented a significant privatization programme in Chile. In 1980s Under the leadership of Margaret Thatcher in the UK and Ronald Reagan in USA, the privatization gained worldwide momentum. A major ongoing privatization of Japan involves Japanese postal Services and largest bank in the World. The Privatization process is expected to last until 2017 (John \& Kikeri, 2002).

\section{Privatization in Sri Lanka}

For the first time, in 1987, the Minister of finance, in his budget speech, drew attention to need for the privatization of loss-making enterprises, in August 1987, a presidential commission was appointed to examine the feasibility of contacting the new privatization programme. The commission, adopting a long-term perspective recommended that profitmaking enterprises should be privatized first. Although the government accepted the recommendations of the commission, their implementation was kept in abeyance due the forthcoming presidential elections. After the election same political party again won the election and restarted the implementation of the privatization program. In 1989, the shares of United Motors came into market starting the privatization.

The People's Alliance government came in to power in 1994 continued the same privatization programme as like before. As a first step, it set up a Task force on Public enterprises. The public enterprises reform Commission of Sri Lanka (PERK) was established under Act No. 1 of 1996 to advise and assist the government on reform of public enterprises and related matters. After establishment of PERK, large scale of enterprises such as the Colombo Gas., Sri Lanka Telecom, Janatha Estate Development Board, State Plantation Corporation and National Development Bank were privatized. 


\section{Data and Methodology}

\section{Operationalization}

The main objective of the study is to evaluate performances of the two companies under two different managements, hence the performance of the selected organizations are measured under financial performance, physical performance and employee satisfaction.

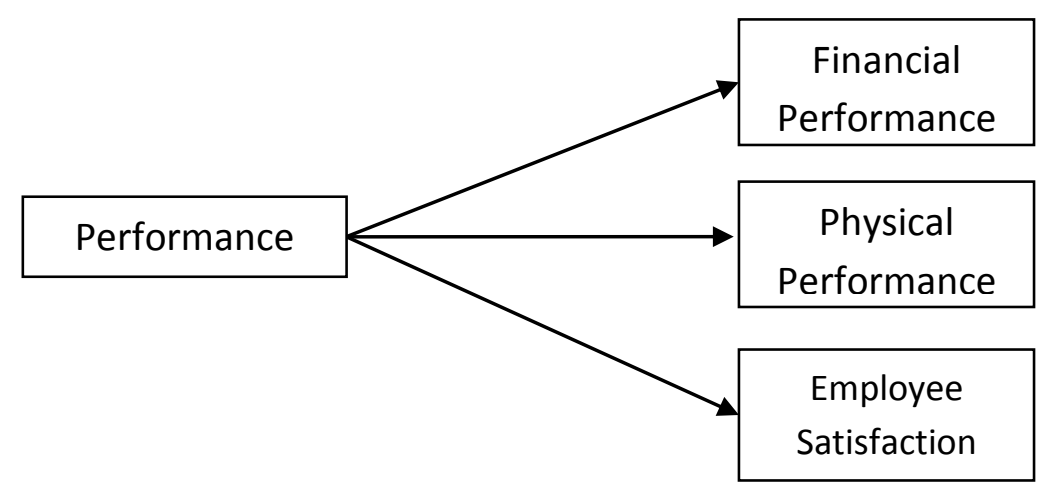

Figure 3.1: Operationalization of performance variables

\section{Operationalization of Financial Performance}

Financial analysis is made to identify the financial performances, strength and weaknesses of the two companies under two different management systems by using financial statements. Profitability, activity and liquidity ratios are used to make the financial judgment about the performance of the two companies.

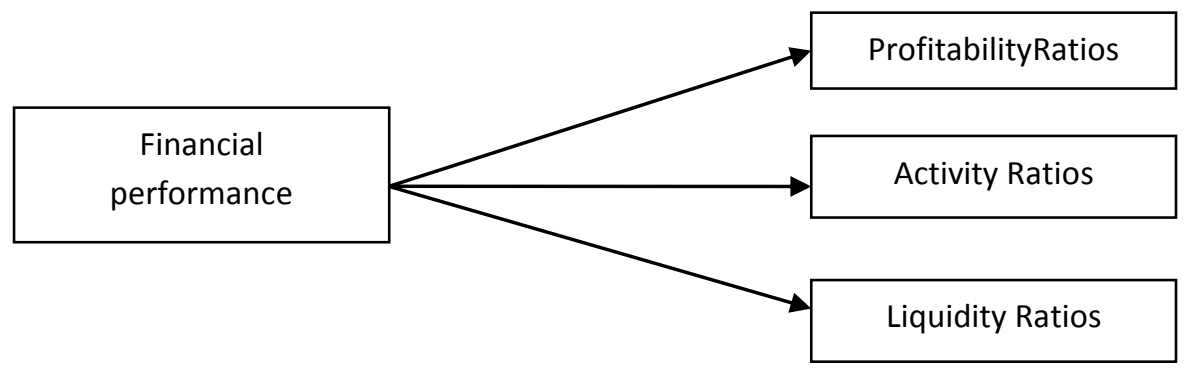

Figure 3.2: Operationalization of financial performance variables

\section{Evaluation of Financial Performance}


Returned on capital employed, Return on equity Gross profit margin and Net profit margin are used to evaluate the financial performance of the companies under two different managements.

Table 3.1: Formula to calculate Profitability Ratios

\begin{tabular}{|l|l|}
\hline Ratio & Formula \\
\hline $\begin{array}{l}\text { Return on capital } \\
\text { employed }\end{array}$ & $\begin{array}{l}\text { Net profit before tax \& interest/Total Assets } x \\
100\end{array}$ \\
\hline Return on equity & Net profit after tax \&interest/share capital $x 100$ \\
\hline Gross profit Margin & Gross profit/Net sales $x 100$ \\
\hline Net Profit Margin & Net Profit/Net Sales $x 100$ \\
\hline
\end{tabular}

Source :( Mc Laney, 1994)

Table 3.2: Formula to calculate Activity Ratios

\begin{tabular}{|l|l|}
\hline Ratio & Formula \\
\hline Asset Turn-over & Sales/ Total assets less current liabilities X 100 \\
\hline Stock-Holding period & Stock held / Cost of Sales $x 365$ days \\
\hline Debtors collection period & Trade Debtors/Credit Sales $x 365$ days \\
\hline
\end{tabular}

Source :( Mc Laney, 1994)

Table 3.3: Formula to calculate Liquidity Ratios

\begin{tabular}{|l|l|}
\hline Ratio & Formula \\
\hline Current ratio & Current assets/Current liabilities \\
\hline Quick assets ratio & Liquid assets/current liabilities \\
\hline
\end{tabular}

Source :( Mc Laney, 1994) 


\section{Operationalization of Physical Performance}

Physical performances are used to evaluate the real situation of the organizations, because the financial performances extracted from financial statements are subject to price levels. Fertilizer usage, employment of labour and hectares used are utilized to make non-financial judgment about performance of the organizations.

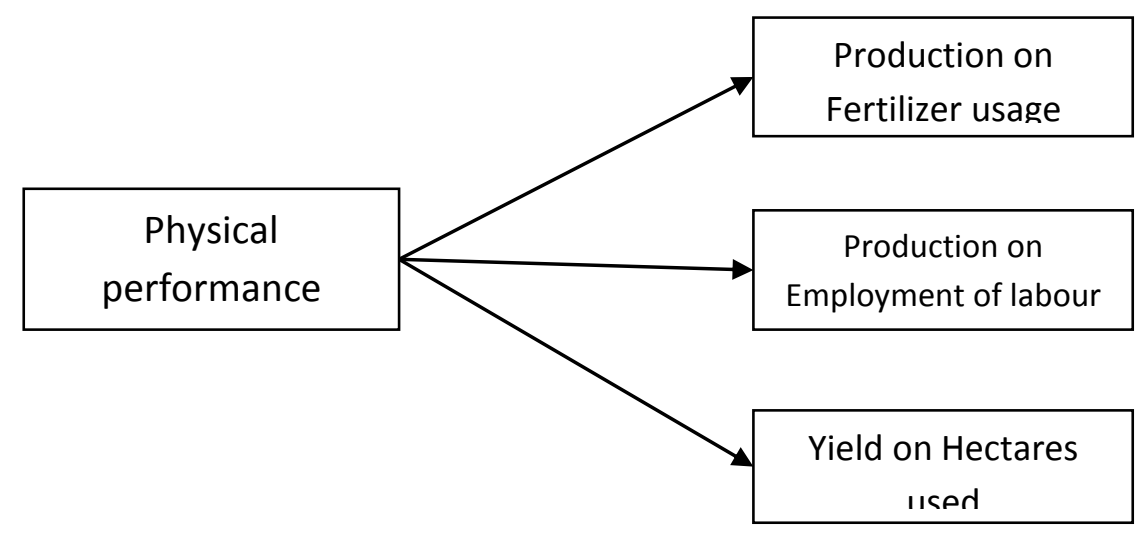

\section{Figure 3.3: Operationalization of physical performance variables}

\section{Evaluation of Physical Performance}

Nuts per fertilizer, Nuts per labour unit and Nuts per hectare are used to evaluate the physical performance under private management and government management.

Table 3.4: Formula to calculate nuts per fertilizer usage

\begin{tabular}{|l|l|}
\hline Ratio & Formula \\
\hline Nuts per fertilizer M.T & $\begin{array}{l}\text { Annual fresh nut production/ Fertilizer used in } \\
\text { previous year }\end{array}$ \\
\hline
\end{tabular}

Source: ( ICFAI centre for Management Research,2003)

Table 3.5: Formula to calculate nuts per Labour unit

\begin{tabular}{|l|l|}
\hline Ratio & Formula \\
\hline Nuts per labour units & $\begin{array}{l}\text { Annual fresh nut production/ Labour units used in } \\
\text { year }\end{array}$ \\
\hline
\end{tabular}

Source: ( ICFAI centre for Management Research,2003) 
Table 3.6: Formula to calculate nuts per Hectare

\begin{tabular}{|l|l|}
\hline Ratio & Formula \\
\hline Nuts per hectare & Annual fresh nut production/ Hectares used \\
\hline
\end{tabular}

Source: ( ICFAI centre for Management Research,2003)

\section{Operationalization of Employee Satisfaction}

Employee satisfaction is depending upon relationship between employer and employee it contributes to high performance of the business organizations. Therefore, facilities, benefits and working environment provided to employees, nature of the work assigned to them and quality of work maintained by the employees are considered as main factors to build up the level of relationship between two parties,

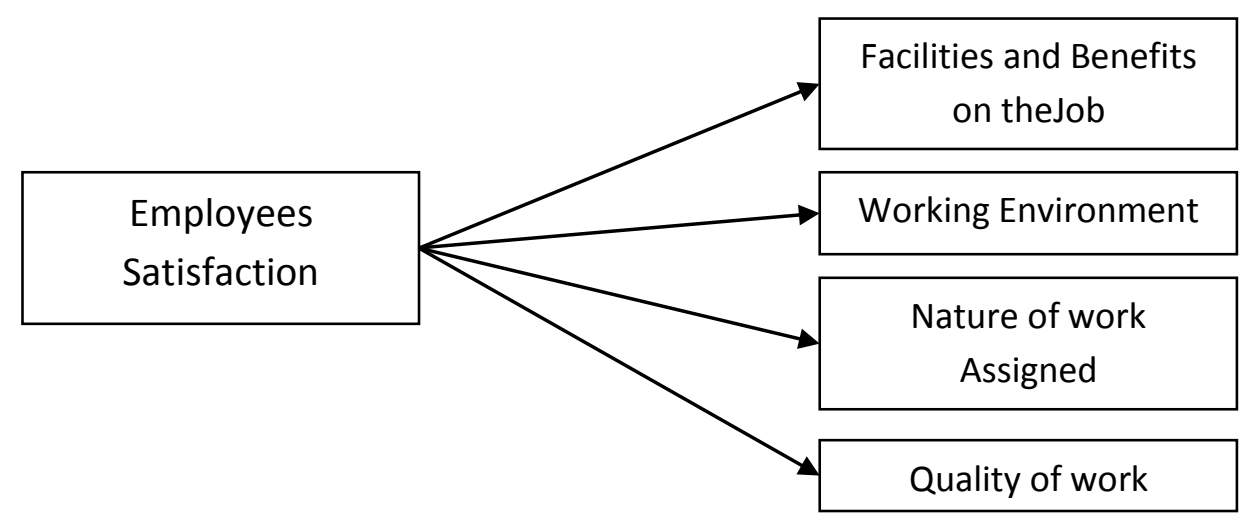

Figure 3.4: Operationalization of physical performance

Source: (ICFAI centre for Management Research -2003)

\section{Results and Discussion}

\section{Financial Performance}

Financial statements of the Kurunegala Plantations Limited and Chilaw Plantation Limited for the period of ten years from the year 2000 to 2009 were used for ratio analysis. In respect of Kurunegala Plantations, a period of five years from the year 2000 to 2004 managed under private management agency and a period of five years from the year 2005 to 2009 managed under government management were taken into consideration. In respect of Chilaw Plantations Limited, a period of eight years from 2000 to 2007 managed under private 
management and a period of two years from 2008 to 2009 managed under government management were taken into consideration.

\section{Analysis of Financial Variables}

The Profitability, efficiency (activity) and liquidity under two different management systems were compared. Return on Capital employed, return on equity, gross profit margin and net profit margin were selected to test the profitability. Net asset turn-over, Stock Holding period, Debtors collection period were selected to test the efficiency (activity). Current Asset and quick asset ratios were selected to test the liquidity. Average (arithmetic mean), standard deviation and co-efficient of variation of selected profitability ratios, activity ratios and liquidity ratios were used to compare the profitability, activity and liquidity under two different management systems.

Table 4.1: Financial Performance

\begin{tabular}{|c|c|c|c|c|c|c|}
\hline \multirow[b]{2}{*}{ Ratio } & \multicolumn{3}{|c|}{ Kurunegala Plantations } & \multicolumn{3}{|c|}{ Chilaw Plantations } \\
\hline & $\begin{array}{l}\text { Under } \\
\text { Private } \\
M g t\end{array}$ & $\begin{array}{l}\text { Under } \\
\text { Govern } \\
\text { ment } \\
\text { Mgt }\end{array}$ & $\begin{array}{l}\text { Increasel } \\
\text { (Decrease } \\
\text { ) }\end{array}$ & $\begin{array}{l}\text { Under } \\
\text { Private } \\
\text { Mgt }\end{array}$ & $\begin{array}{l}\text { Under } \\
\text { Government } \\
\text { Mgt }\end{array}$ & $\begin{array}{l}\text { Increasel } \\
\text { (Decrease) }\end{array}$ \\
\hline $\begin{array}{l}\text { Return on Capital } \\
\text { Employed } \\
\text { Coefficient of } \\
\text { Variation }\end{array}$ & $\begin{array}{l}4.59 \% \\
56.75 \%\end{array}$ & $\begin{array}{l}11.60 \% \\
40.97 \%\end{array}$ & $\begin{array}{c}7.01 \% \\
-15.78 \%\end{array}$ & $\begin{array}{l}11.2 \% \\
31.79 \%\end{array}$ & $\begin{array}{l}17.98 \% \\
18.92 \%\end{array}$ & $\begin{array}{c}6.78 \% \\
-12.87 \%\end{array}$ \\
\hline $\begin{array}{l}\text { Return on Equity } \\
\text { Coefficient of } \\
\text { Variation }\end{array}$ & $\begin{array}{l}3.49 \% \\
151.37 \%\end{array}$ & $\begin{array}{l}13.67 \% \\
47.42 \%\end{array}$ & $\begin{array}{l}10.18 \% \\
-103.95 \%\end{array}$ & $\begin{array}{l}10.68 \\
33.16 \%\end{array}$ & $\begin{array}{l}17.37 \\
29.03 \%\end{array}$ & $\begin{array}{l}6.69 \% \\
-4.13 \%\end{array}$ \\
\hline $\begin{array}{l}\text { Gross Profit Margin } \\
\text { Coefficient of } \\
\text { Variation }\end{array}$ & $\begin{array}{l}29.84 \% \\
44.51 \%\end{array}$ & $\begin{array}{l}35.42 \% \\
19.85 \%\end{array}$ & $\begin{array}{c}5.58 \% \\
-24.66 \%\end{array}$ & $\begin{array}{l}46.01 \% \\
17.81 \%\end{array}$ & $\begin{array}{l}46.08 \% \\
27.77 \%\end{array}$ & $\begin{array}{l}0.07 \% \\
+9.96 \%\end{array}$ \\
\hline $\begin{array}{l}\text { Net Profit Margin } \\
\text { Coefficient of } \\
\text { Variation }\end{array}$ & $\begin{array}{l}17.81 \% \\
56.11 \%\end{array}$ & $\begin{array}{l}29.21 \% \\
26.79 \%\end{array}$ & $\begin{array}{l}11.4 \% \\
-29.32 \%\end{array}$ & $\begin{array}{l}43.11 \% \\
19.23 \%\end{array}$ & $\begin{array}{l}51.7 \% \\
14.34 \%\end{array}$ & $\begin{array}{l}8.59 \% \\
-4.89 \%\end{array}$ \\
\hline $\begin{array}{l}\text { Net Asset Turn-over } \\
\text { Coefficient of }\end{array}$ & $\begin{array}{l}28.14 \% \\
14.77 \%\end{array}$ & $\begin{array}{l}44.90 \% \\
17.75 \%\end{array}$ & $\begin{array}{r}17.75 \% \\
2.98 \%\end{array}$ & $\begin{array}{l}27.20 \\
18.40 \%\end{array}$ & $\begin{array}{l}37.18 \\
5.14 \%\end{array}$ & $\begin{array}{l}9.98 \% \\
-13.26 \%\end{array}$ \\
\hline
\end{tabular}




\begin{tabular}{|c|c|c|c|c|c|c|}
\hline Variation & & & & & & \\
\hline $\begin{array}{l}\text { Stock Holding Period } \\
\text { (Days) } \\
\text { Coefficient of } \\
\text { Variation }\end{array}$ & $\begin{array}{l}39 \\
22 \%\end{array}$ & $\begin{array}{l}34 \\
17 \%\end{array}$ & $\begin{array}{l}(5) \\
-5 \%\end{array}$ & $\begin{array}{l}89 \\
29 \%\end{array}$ & $\begin{array}{l}73 \\
52 \%\end{array}$ & $\begin{array}{l}(16) \\
+23 \%\end{array}$ \\
\hline $\begin{array}{l}\text { Debtors Collection } \\
\text { Period(days) } \\
\text { Coefficient of } \\
\text { Variation }\end{array}$ & $\begin{array}{l}66 \\
11 \%\end{array}$ & $\begin{array}{l}37 \\
15 \%\end{array}$ & $\begin{array}{l}(29) \\
+4 \%\end{array}$ & $\begin{array}{l}28 \\
36 \%\end{array}$ & $\begin{array}{l}28 \\
29 \%\end{array}$ & $\begin{array}{l}0 \\
-7 \%\end{array}$ \\
\hline $\begin{array}{l}\text { Current Asset Ratio } \\
\text { (Times) } \\
\text { Coefficient of } \\
\text { Variation }\end{array}$ & $\begin{array}{l}0.67 \\
32.02 \%\end{array}$ & $\begin{array}{l}1.21 \\
52.47 \%\end{array}$ & $\begin{array}{l}0.54 \\
20.45 \%\end{array}$ & $\begin{array}{l}8.13 \\
20.8 \%\end{array}$ & $\begin{array}{l}7.99 \\
4.65 \%\end{array}$ & $\begin{array}{l}(0.14) \\
-16.15 \%\end{array}$ \\
\hline $\begin{array}{l}\text { Quick Assets (Times) } \\
\text { Coefficient of } \\
\text { Variation }\end{array}$ & $\begin{array}{l}0.51 \\
44.70 \%\end{array}$ & $\begin{array}{c}0.98 \\
58.54 \%\end{array}$ & $\begin{array}{l}13.16 \\
13.84 \%\end{array}$ & $\begin{array}{l}7.34 \\
21.58 \%\end{array}$ & $\begin{array}{l}7.21 \\
5.81 \%\end{array}$ & $\begin{array}{l}(0.13) \\
-15.77 \%\end{array}$ \\
\hline
\end{tabular}

Source: Compiled by author using annual reports 2002 to 2009

This reveals that profitability of the both companies has materially enhanced during the period under government management. Reduction of the coefficient of variations of the all other profitability ratios except the gross profit margin ratio of Chilaw plantations explains that generation of profits of the both companies were stable under the government management.

In addition both companies have efficiently performed during the period under government management when compared with private sector management. Coefficient of variations of the all other activity ratios except the net asset turn-over and debtors collection period of Kurunegala plantations have reported that both companies were performed smoothly under government management.

Liquidity position of the Kurunegala plantations has increased although coefficient of variations has increased due to quick improvement in the liquidity situation under the government management. It also noted that liquidity position of the Chilaw plantations reduced due to the fact that the company was compelled to pay Rs. 140 Million for relinquishment of management right. However coefficient of variation of the liquidity of the 
Chilaw plantations indicated the stability of the fund management under government management.

\section{Physical Performance}

Data for the period of eight years from 2002 to 2009 were used for the analysis of input and output of the operational activities of the companies. Fertilizer and direct labor were observed as direct input for yield. In respect of Kurunegala Plantations, a period of three years from the year 2002 to 2004 and a period of four years from the year 2006 to 2009 managed under private agency and government respectively were considered. In respect of Chilaw Plantations, a period of six years from 2002 to 2007 and a period of two years from 2008 to 2009 managed under private agency and management under government respectively were considered.

\section{Analysis of Physical Variables}

Annual production, utilization of direct inputs and relationship between input and output were examined to compare the physical performance under the two management systems.

Annual production under different managements and its average and co-efficient of variation were considered to compare under which management the companies were able to achieve higher production levels.

Fertilizer and labour were identified as the main direct input factors for this industry. Therefore utilization of fertilizer and labour were analyzed to evaluate usage of direct input under the two different managements. In addition, yield per fertilizer metric ton and yield per labour unit were calculated to examine the productivity under the two different management systems. Further relationship between input and output was tested to evaluate effectiveness of the input utilization under the two different managements.

Further it is observed that significant extent of land have been used in this industry. Therefore, production per hectare was calculated to examine the effectiveness of the land utilization because value of the land investment is substantial and material. 
Table 4.2: Physical performance 1

\begin{tabular}{|c|c|c|c|c|c|c|}
\hline \multirow[b]{2}{*}{ Ratio } & \multicolumn{3}{|c|}{ Kurunegala Plantations } & \multicolumn{3}{|c|}{ Chilaw Plantations } \\
\hline & $\begin{array}{l}\text { Under } \\
\text { Private } \\
\text { Mgt }\end{array}$ & $\begin{array}{l}\text { Under } \\
\text { Govern } \\
\text { ment } \\
\text { Mgt }\end{array}$ & $\begin{array}{l}\text { Increasel } \\
\text { (Decreas } \\
\text { e) }\end{array}$ & $\begin{array}{l}\text { Under } \\
\text { Private } \\
\text { Mgt }\end{array}$ & $\begin{array}{l}\text { Under } \\
\text { Govern } \\
\text { ment } \\
\text { Mgt }\end{array}$ & $\begin{array}{l}\text { Increasel } \\
\text { (Decreas } \\
\text { e) }\end{array}$ \\
\hline $\begin{array}{l}\text { Coconut Production, } \\
1000 \\
\text { Coefficient of Variation }\end{array}$ & $\begin{array}{l}13,326 \\
2.59 \%\end{array}$ & $\begin{array}{l}15,002 \\
14.72 \%\end{array}$ & $\begin{array}{l}+1,676 \\
+12.13 \%\end{array}$ & $\begin{array}{l}16,706 \\
9.66 \%\end{array}$ & $\begin{array}{l}17,455 \\
9.5 \%\end{array}$ & $\begin{array}{l}+749 \\
-0.16 \%\end{array}$ \\
\hline $\begin{array}{l}\text { Labor Utilization } \\
\text { Coefficient of Variation }\end{array}$ & $\begin{array}{l}125,549 \\
3.68 \%\end{array}$ & $\begin{array}{l}260,169 \\
15.91 \%\end{array}$ & $\begin{array}{l}+134,620 \\
+12.23 \%\end{array}$ & $\begin{array}{c}154,046 \\
7.03 \%\end{array}$ & $\begin{array}{l}180,729 \\
11 \%\end{array}$ & $\begin{array}{l}+26,683 \\
+3.97 \%\end{array}$ \\
\hline $\begin{array}{l}\text { Nuts per Labor Unit } \\
\text { Coefficient of Variation }\end{array}$ & $\begin{array}{l}105 \\
6.09 \%\end{array}$ & $\begin{array}{l}58 \\
14.41 \%\end{array}$ & $\begin{array}{l}-47 \\
+8.32 \%\end{array}$ & $\begin{array}{l}109 \\
12.5 \%\end{array}$ & $\begin{array}{l}97 \\
1 \%\end{array}$ & $\begin{array}{l}-12 \\
+11.5 \%\end{array}$ \\
\hline $\begin{array}{l}\text { Fertilizer Application, } \\
M T \\
\text { Coefficient of Variation }\end{array}$ & $\begin{array}{l}509 \\
13.77 \%\end{array}$ & $\begin{array}{l}360 \\
21.86 \%\end{array}$ & $\begin{array}{l}-149 \\
+8.09 \%\end{array}$ & $\begin{array}{l}1,614 \\
10.47 \%\end{array}$ & $\begin{array}{l}1,345 \\
43 \%\end{array}$ & $\begin{array}{l}-269 \\
+32.53 \%\end{array}$ \\
\hline $\begin{array}{l}\text { Nuts per Fertilizer, MT } \\
\text { Coefficient of Variation }\end{array}$ & $\begin{array}{l}26,261 \\
10.79 \%\end{array}$ & $\begin{array}{l}43,784 \\
29.16 \%\end{array}$ & $\begin{array}{l}+20,523 \\
+18.37 \%\end{array}$ & $\begin{array}{l}10,453 \\
12.59 \%\end{array}$ & $\begin{array}{l}14,601 \\
52 \%\end{array}$ & $\begin{array}{l}+4,148 \\
+39.41 \%\end{array}$ \\
\hline $\begin{array}{l}\text { Hectares Used } \\
\text { Coefficient of Variation }\end{array}$ & $\begin{array}{l}4,040 \\
0.30 \%\end{array}$ & $\begin{array}{l}3,785 \\
2.47 \%\end{array}$ & $\begin{array}{l}-255 \\
+2.17 \%\end{array}$ & $\begin{array}{l}6,061 \\
0.78 \%\end{array}$ & $\begin{array}{l}5,983 \\
1 \%\end{array}$ & $\begin{array}{l}-78 \\
+022 \%\end{array}$ \\
\hline $\begin{array}{l}\text { Nuts per Hectare } \\
\text { Coefficient of Variation }\end{array}$ & $\begin{array}{l}3,273 \\
2.73 \%\end{array}$ & $\begin{array}{l}3,975 \\
16.41 \%\end{array}$ & $\begin{array}{l}+702 \\
+13.68 \%\end{array}$ & $\begin{array}{l}2,756 \\
9.5 \%\end{array}$ & $\begin{array}{l}2,918 \\
10 \%\end{array}$ & $\begin{array}{l}+162 \\
+0.5 \%\end{array}$ \\
\hline
\end{tabular}

Source: Compiled by author using annual reports 2000 to 2009

It reveals that coconut production of the both companies has increased under the government management. Coefficient of variation of the coconut production of the kurunegala plantations under the government management was increased due to the large increase of the production. It explains that potential of the plantations were not identified by the private management. Coefficient of variation of the coconut production of the Chilaw plantations under the government management explains the stability of production. 
Table 4.3: Physical performance 11

\begin{tabular}{|l|l|l|l|l|}
\hline & \multicolumn{2}{|l|}{ Kurunegala Plantations } & \multicolumn{2}{l|}{ Chilaw Plantations } \\
\hline Ratio & $\begin{array}{l}\text { Private Mgt }- \\
\text { Correlation } \\
\text { Coefficient }\end{array}$ & $\begin{array}{l}\text { Government Mgt } \\
- \text { Coefficient }\end{array}$ & $\begin{array}{l}\text { Private Mgt }- \\
\text { Correlation } \\
\text { Coefficient }\end{array}$ & $\begin{array}{l}\text { Government } \\
\text { Mgt } \\
\text { Correlation } \\
\text { Coefficient }\end{array}$ \\
\hline Labor Utilization & -0.83 & 0.53 & -0.11 & 1 \\
\hline Fertilizer Utilization & 0.91 & -0.36 & 0.17 & -1 \\
\hline
\end{tabular}

Source: Compiled by author using annual reports 2000 to 2009

Labour utilization of the both companies has significantly increased under the government management and this was the one of the main reason of the enhancement the total production. This confirms the change in correlation coefficient from negative value to positive value during the period under government management. However as a result of the material increase of labour under the government management nuts per labour of the both companies has come down. As a result coefficient of variation has increased.

Increase in total coconut production of both companies with fertilizer application during the period under government explains that period under the private management, no fertilizer application has been made with proper technical requirements. This confirms the change in correlation coefficient from positive value to negative during the period under government management. It can be easily understood by analyzing the nuts per fertilizer Metric ton. Nuts per fertilizer Metric ton have been increased in both companies.

Nuts per hectare of both companies have increased during the period under government management. It indicates that low productive lands have been removed and utilized for suitable investments.

\section{Employees' Satisfaction}

Employees' satisfaction was examined under part III of this analysis to evaluate which management is better in respect of managing human resources because it affects the performances of the operations directly. A questionnaire was used to obtain information about their jobs and satisfaction from 100 employees who have worked in the two companies under both management systems. 


\section{Analysis of Variables of Employees' Satisfaction}

Data for evaluation of the employee satisfaction is collected through questionnaire designed to cover all the types employees in the sample population. It was developed hypothesis that $\left(\mathrm{H}_{\mathrm{o}}\right)$ there is no significant difference in the employee satisfaction under two different management systems and $\left(\mathrm{H}_{1}\right)$ there is a significant difference in the employee satisfaction under two different management systems.

Under this situation it is needed to compare the degree of evaluations made by the employees under two different management systems. Chi-square test of goodness of fit is a test statistics used to test a hypothesis that provides a set of expected values with which observed values are compared. (ICFAI, 2004). Therefore Chi-square test was applied to examine the degree of the acceptance of the employees under given scales, that if there is a difference under two management systems.

Table 1: Data outliers of test variables

\begin{tabular}{|l|l|l|l|l|l|l|}
\cline { 2 - 8 } \multicolumn{1}{c|}{} & \multicolumn{2}{l|}{$\begin{array}{l}\text { Kurunegala } \\
\text { Plantations }\end{array}$} & \multicolumn{3}{l|}{ Chilaw Plantations } \\
\hline Test Statistics & $\begin{array}{l}\text { Chi- } \\
\text { Square } \\
(a, b)\end{array}$ & $d f$ & $\begin{array}{l}\text { Asymp } \\
. \text { Sig }\end{array}$ & $\begin{array}{l}\text { Chi- } \\
\text { Square } \\
(a, b)\end{array}$ & $d f$ & $\begin{array}{l}\text { Asymp. } \\
\text { Sig }\end{array}$ \\
\hline Analysis of Facilities and Benefits & 70.889 & 12 & 0.000 & 23.737 & 16 & .095 \\
\hline Analysis of Working Environment & 56.444 & 12 & 0.000 & 30.842 & 11 & .001 \\
\hline Analysis of Nature of Work Assigned & 96.222 & 9 & 0.000 & 23.947 & 10 & .008 \\
\hline Analysis of Quality of Works & 60.50 & 8 & 0.000 & 33.053 & 8 & .000 \\
\hline
\end{tabular}

Source: Compiled by author using questionnaire

Chi square test reveals that in respect of Kurunegala plantations, there are significant differences under the two management systems in the all observations compared with expected values. Therefore null hypothesis should be rejected. It explains that employee perception is clearly different under the two different management systems.

in respect of Chilaw plantations, there are significant differences under the two management systems in the other all observations compared with expected values except the facilities and 
benefits. Therefore null hypothesis should be rejected in connection with all other observations except facilities and benefits. It explains that employee perception is different under two different management systems except facilities and benefits.

\section{Conclusion \& Recommendations}

\section{Financial Performance}

Research findings highlights the overall profitability, activity and liquidity of the both companies have improved under the government management when compared with period under private management. Utilization of resources, working capital management are more efficient and effective.

In contrast to the findings of the empirical studies of the Megginson et al (1994), D' Souza and Megginson (1999) and D Souza et al (2001) financial performances of both companies have been improved during the period under government management.

\section{Physical Performance}

According to this research overall productivity of the both companies have increased under government management. This results also contrast with findings documented in empirical studies of the Megginson et al (1994), D’ Souza et al (1999) and D' Souza et al (2001).

\section{Employee Satisfaction}

\section{Results of Statistical Analysis}

When the Kurunegala plantations is considered, all variables referred in the analysis has confirmed that there is an employee satisfaction under government management, While the Chilaw plantations is considered, except the facilities and benefits on the job other variables has confirmed the employee satisfaction in the company under government management.

Under these circumstances, it confirms the improvement in employee satisfaction of both companies under government management instead to the findings of job security in empirical studies of the Megginsonetal (1994), D’ Souza etal (1999) and D' Souza etal (2001).

\section{Recommendations}

It is evident that, in Sri Lanka, owners of coconut plantations has diverged the lands invested to the coconut plantations to other high return investments such as housing projects, garment 
factories and as a result there is a significant decrease in the coconut production. Under this situation it is advisable to maintain the plantation under government control.

Implementations of these rules and regulations in the government circulars disturb the freedom of the managers of the companies, in making business decisions compared with private sector. Therefore unnecessary red tapes should be removed.

The devisable risk in the companies should be eliminated through diversification. Diversification of coconut plantations can be made for dairy industry and other seasonal plantations such as pepper, coffee and plantains, etc.

The employees of the company have to be motivated through financial benefits and other non-financial facilities provided to them. This may affect positively to the performance of the companies.

\section{References}

Abel, D. (1957). British Conservatives and State Ownership”, Journal of Politics, Vol.19, pp 227-39

Abromeit, H. (1986). An Industry Between the State and the Private Sector British Steel : $328 \mathrm{pp}$

Akram, T. (1998a). Entry, Exit, Efficiency \&The Question of Privatization Centre for Policy Dialogue Working Paper

Annual Reports, (2000-2009). Kurunegala Plantations Limited \&Chilaw Plantations Limited

Ashworth William, (1986). The History of the British Coal Industry, Volum 5, 1946-1982: The Nationalized Industry

Athukorala, P. \&Jayasuriya, S. (1994). Macroeconomic Policies,Crises, and Growth in Sri Lanka. 1960-90 World Bank

Barney,J.B (1996). Gaining and sustaining competitive advantage, Reading MA: Addison Wesley

Bailey, Elizabeth E. (1986). Price and Productivity change Following deregulation, The U.S experience. Economic Journal, 96,96-117 
Birdsall, N \&Nellis,J.(2006).Winners and Losers: Assessing the Distributional Impact of Privatization", CGD Working Paper No 6 (PDF)

Bishop Matthew R., and John A. Kay, (1989), "Privatization in the United Kindom: Lessons from experience”, World Development, 643,657

CabinatMemorandom, (2007): Minister of public Estate Management and Developmen.

Caves, Richard E., (1990), "Lessons from Privatization in Britain: State enterprise behavior, public choice, and corporate governance", Journal of Economic Behavior and Organization 13, 145-169

Central Bank of Sri Lanka (1988: 211), Annual Report

Cuervo, A \& Belen Villalonga (2000)," Explaning the variance in the performance effects of Privatizaton, “Academy of Management Review, Vol.23 No.3, 581-590 .

D' Souza, Juliet and Megginson,W. L (1999) “ The financial and operating performance of privatized firms during the 1990s"

D’ Souza, Juliet and Megginson,W. L (1998), "Sources of performance improvement in privatized firms: Evidence from the telecommunications Industry", Working paper, University of Oklahoma

Dagdeviren (2006), "RevisitingPrivatizationin the context of poverty allevation" Journal of International Development, Vol. 18,469-488

De Silva,K.M. (1977), “Sri Lanka : A Survay’,London, Hurst and Company

Foreman-Peck, James. (1994): "Public and Private Ownership of British Industry", 18201990. $386 \mathrm{pp}$

Gaitskell, H (1956): “Socialism and Nationalization”, Fabian Tract 300,pp5-7 and 31-36

Gillingham,J(1991): “ Coal, Steel, and the rebirth of Europe, 1945-1955; Derek W. Urwin, (1995) "The Community of Europe" : A History of European Integration since 1945

Government Corporation Act, No 19 of 1953

Government Sponsored Act, No 19 of 1955 
Goodman, John B., and Gray W. Loveman, (1992)," Does privatization serve the public interest?",Harward Business Review. 26-38

Gunatilleke, G (2000), “Sri Lanka's Development since Independence”, in W.D. Lakshman (ed.), Development Policy Regimes, New York, N.S.P

Hannah, Leslie (1982): "The First Fifteen Years of Nationalized Electricity Supply in Britain”, Engineers, Managers, and Poloticians.333 pp

Hanson, A.H. (1963), "Nationalization”, George Allen and Unwin Ltd

ICFAI Center for Managemet Research, Banjara Hills, Hyderabad,(2003), "Introduction to Management"

International LabourOrganization: Managing the privatization and restructuring Public utilities, 1999.

Johnman, Lewis (1996): “The Privatization of British Shipbuilders", International Journal of Maritime History, 8(2): 1-31

Karunaratna, N.D. (1973), "Techno- Economic Survay of industrial Potential in Sri Lanka, Colombo, Industrial Development Board.

Karunaratna, N.D. (2000) "Sri Lanka's Development since Independence", in W.D. Lakshman(ed.), The Export Engine of Growth in Post Independence Sri Lanka, New York, N.S.P

Kay,J.A and D.J. Thompson, (1986) “ Privatization: A policy in search in rationale, Economoc Journal 96,18,38

Kelegama ,Saman,(1995 ), "The impact of privatization on distributional equity": the case of Sri Lanka"

Khan, Imran (2006) "Publicvs. private sector : An Examination of neo-liberal ideology"

Lieberman S (1981): “The ideological Foundations of Western European planning”, Journal of European Economic History 10 (2) : 343-371

Lucy,T .1988) “Management Accounting “, 2 $2^{\text {nd }}$ Edition, Book Power with Cengage Learning 
Luthans, F.(1998) “Organization Behavior” Eighth edition, India: Irwin McGraw -Hill

McLaneyE . J. (1994), "Business Finance for Decision Makers" $2^{\text {nd }}$ edition, Polymouth Business School - University of Polymiuth

Megginson, W. L., Nash, R.C and Van Randenborgh, M (1994) "The Financial and operating performance of newly privatized firms": An international empirical ananlysis, Journal of Finance 49,403-452.

Megginson, W.L \& Jeffery M.N (2001), "From state to Market: A Survey of Empirical studies on Privatizaton”(PDF) Journal of Economic Literature

Memorandom of understanding (2008) Chilaw Plantations PLC Limited \&Wayamba Plantations Pvt Limited.

Minisrty of Public Estate Management \& Development, (2005-2009) "Progress Reports"

Millward, Robert (1997): “The 1940s nationalizations in Britain: Means to an End or Means of Production?” Economic History Review 50 (2): 209-234.

Millward, Robert and Singleton, John, eds.(1995): “ The Political Economy of Nationalization in Britain” 1920-1950. 325 pp

Nellis, john and SunitaKikeri, (1992) "Privatization: The lessons of experience" (Washington, DC, World Bank).

Nellis, j. and SunitaKikeri, (2002) "Privatization in Competitive Sectors": World Bank Polocy Research Working Paper No 2860

Oliver, M.H., Jr. (1957), Economic Opinion and Policy in Ceylon, Duke University, London, Commonwealth Study Center

Pandy, I.M (2005), “Financial Management”, $9^{\text {th }}$ edition, Vikas Publishing House Pvt Ltd

Patabendige, A. (2006), "Industrial Policies and Employment Generation in Sri Lanka"

Public Alliance, Sri Lanka: Manifesto of President Election (2005) "MahindaChintana"

Price Waterhouse, (1989a)," Privatization": Learning the Lessons from U.K experience (London, U.K). 
Price Waterhouse, (1989a), "Privatization ": The Facts (London, U.K).

Pryke, Richard, (1982),'The comparative performance of public and private enterprises", Fiscal Studies 3, 68,81.”

Report of the Industries Commission,(1922), Sessional Paper, No.1, Ceylon Government Press, Colombo

Robbins, Stephen P. \& Mary Coulter (2002), "Management" First Indian Reprint.Delhi: Pearson Education Inc

Sattler, Thomas P. And Julie E. Mullen,(2001)." Enhancing Job Satisfaction and Productivity"

Shirley,Mary and John Nellis (1991)," Public Enterprise Reform”: The lessons of Experience (The World Bank, Washinton,D.C)

Snodgrass, D.R. (1944), Ceylon: “An Export Economy in Transition”, Economic Growth Center, Yale University, Irwin Inc, New Haven

The Ceylon Banking Commission, (1934), Report of the Ceylon Banking Commission ,Ceylon Government Press, Colombo

The State Industrial Corporation's Act No. 49 of 1957

Trade Union Congress: Interim Report on Post- War Reconstruction,(1944), paras 26-36, 37$40,90-104$

Wortzel,Heidi V., and Lawrence H. Wortzel (1989) "Privatization" : Not the only answer, World Development , $633-641$ 